Dikirim: 17 Januari 2017 Diterbitkan: 1 Juli 2017

\title{
Stres psikososial dan kejadian kandidiasis vulvovaginalis (KVV) pada wanita pekerja seks di Banyumas
}

\section{Psychosocial stress and vulvovaginal Candidiasis among female sex workers in Banyumas}

Leyna Chunaifa ${ }^{1}$, Baning Rahayujati ${ }^{1}$, Yayi Suryo Prabandari ${ }^{2}$

\begin{abstract}
Purpose: This study aimed to determine the relationship between psychosocial stress with candidiasis vulvovaginalis (KVV) incidence in female sex workers (FSW). Methods: The research design was a case control study conducted in health center clinics in the Banyumas District. The sample size was 164 FSW (82 cases \& 82 control). The research instrument was structured questionnaires, Social Readjustment Rating Scale (SRRS), laboratory equipment and microscopes for inspection KVV. Data analysis used logistic regression tests to calculate odds ratios (OR), confidence interval $(\mathrm{Cl})$, and $p$ value. Results: The multivariate analysis showed that stress was not KVV risk factors, and the risk factors that contribute to the occurrence of $\mathrm{KVV}$ in $\mathrm{FSW}$ were oral $\operatorname{sex}(\mathrm{OR}=3.31,95 \% \mathrm{Cl}=1.60$ to 6.83 , $p$-value $=0.001)$ and smoking more than 10 cigarettes $/$ day $(O R=2.33,95 \% \mathrm{Cl}$ $=1.2$ to $4.59, p$-value $=0.014)$. Conclusions: The risk factors of KVV were oral sex and smoking $\geq$ ten cigarettes/day. We recommend to avoid oral sex and smoking < ten cigarettes/day to avoid the risk of KVV infection.
\end{abstract}

Keywords: stress psychosocial; candidiasis vulvovaginal; female sex worker; case control

\footnotetext{
${ }^{1}$ Departemen Biostatistik, Epidemiologi dan Kesehatan Populasi, Fakultas Kedokteran, Universitas Gadjah Mada (leyna.chunaifa@gmail.com)

2 Departemen Perilaku Kesehatan, Lingkungan dan Kedokteran Sosial, Fakultas Kedokteran, Universitas Gadjah Mada
} 


\section{PENDAHULUAN}

Kandidiasis vulvovaginal (KVV) adalah infeksi mukosa yang disebabkan oleh spesies Candida. Kandidiasis merupakan salah satu masalah klinis yang paling umum dialami wanita pada usia produktif. Sebanyak $75 \%$ wanita akan mengalami setidaknya satu episode kandidiasis dalam hidup, dengan proyeksi $50 \%$ dari semua wanita mengalami beberapa episode (1). Kelompok usia 20-24 tahun pada pria dan wanita, pekerja seks komersial, homoseksual dan pecandu narkotika berisiko tinggi untuk terkena Infeksi Menular Seksual (IMS). Data klinik infeksi menular seksual di Kabupaten Banyumas pada tahun 2011 menunjukkan terdapat 1204 orang positif infeksi menular seksual.

Beberapa faktor dapat meningkatkan risiko kandidiasis, antara lain usia, kehamilan, obesitas, terapi antibiotika, terapi imunosupresif, dan kanker (2). Perilaku seksual, meliputi cara berhubungan seksual maupun frekuensi hubungan seks dapat meningkatkan risiko kandidiasis (3). Umur dan merokok juga merupakan faktor yang berhubungan kejadian kandidiasis. Usia< 40 tahun merupakan faktor risiko dan berhubungan dengan kejadian kandidiasis (4). Stres psikososial diketahui dapat menekan sel mediator yang berfungsi sebagai sistem imun tubuh untuk melawan infeksi, termasuk infeksi candida albicans. Sejauh ini, belum ada penelitian terkait stres psikososial pada Wanita Pekerja Seks (WPS) yang dikaitkan dengan kejadian kandidiasis di Indonesia. Penelitian ini bertujuan untuk mengetahui hubungan antara stres psikososial dengan kejadian kandidiasis.

\section{METODE}

Penelitian analitik observasional dengan rancangan case control dilakukan di klinik IMS puskesmas di Banyumas pada bulan September tahun 2016 dengan sampel sebanyak 164 WPS (kasus: 82 orang dan kontrol: 82 orang). Pengambilan sampel dilakukan secara purposif dengan prinsip keterjangkauan wilayah serta memenuhi kriteria inklusi, yaitu berusia $>18$ tahun dan bersedia menjadi responden yang disertakan pernyataan persetujuan (informed consent). Kriteria eksklusi memiliki riwayat kandidiasis $>4$ kali dalam setahun terakhir, memiliki penyakit diabetes melitus, hamil, dan mengonsumsi antibiotik dalam seminggu terakhir yang didapat dari anamnesis dokter dan rekam medis. Variabel independen penelitian adalah stres psikososial, variabel dependen kandidiasis vulvovaginal, serta variabel potensial pemicu meliputi umur, kegemukan, merokok, jumlah pasangan seksual, dan frekuensi hubungan seksual.

Instrumen yang digunakan dalam pengumpulan data yaitu kuesioner faktor risiko KVV dan kuesioner stresor psikososial yang diadopsi dari kuesioner Social Readjusment Rating Scale (5) yang telah diterjemahkan dan divalidasi oleh Sumedhi dan sudah di validasi (6). Analisis data dilakukan dengan uji logistic regression.

\section{HASIL}

Tabel 1 menunjukkan karakteristik responden. Rata-rata responden berusia 25 tahun dan berhubungan seksual pertama kali pada usia 18 tahun. Rata-rata responden menjadi WPS pada umur 23 tahun dan telah menjadi WPS selama 21 bulan. Sebagian besar responden berpendidikan SMP dengan Status perkawinan cerai hidup.

Tabel 1 Karakteristik responden

\begin{tabular}{lcc}
\hline \multicolumn{1}{c}{ Karakteristik } & Mean \pm sd & Min-max \\
\hline Umur & $25,49 \pm 5,42$ & $18-49$ \\
Umur pertama kali & $18,41 \pm 2,53$ & $12-28$ \\
berhubungan & & \\
seksual & & \\
Umur menjadi WPS & $23,63 \pm 4,28$ & $17-39$ \\
Lama menjadi WPS & $21,29 \pm 28,34$ & $1-120$ \\
(bulan) & & \\
\hline & Total & Persentase (\%) \\
& $(\mathrm{n}=164)$ & \\
Tingkat pendidikan & & \\
SD SMP SMA & 36 & 21,95 \\
Akademi/PT & 93 & 56,71 \\
& 34 & 20,73 \\
Status perkawinan & 1 & 0,61 \\
Belum kawin & & \\
Kawin & 43 & 26,22 \\
Cerai hidup & 28 & 17,07 \\
Cerai mati & 89 & 54,27 \\
\end{tabular}

Tabel 2 menunjkkan hasil hubungan beberapa variabel bebas secara bersama-sama dengan variabel terikat.

Tabel 2. Odd ratio dan $p$-value variabel

\begin{tabular}{|c|c|c|c|c|}
\hline \multirow[b]{2}{*}{ Variabel } & \multicolumn{2}{|c|}{ Model 1} & \multicolumn{2}{|c|}{ Model 2} \\
\hline & $\begin{array}{c}\text { OR } \\
95 \% C I\end{array}$ & p-value & $\begin{array}{c}\text { OR } \\
95 \% C I\end{array}$ & p-value \\
\hline Stres & $\begin{array}{c}1,30 \\
0,59-2,81\end{array}$ & 0,512 & $\begin{array}{c}1,45 \\
0,68-3,08\end{array}$ & 0,339 \\
\hline Jumlah rokok & $\begin{array}{c}2,40 \\
1,21-4,74\end{array}$ & $0,012^{*}$ & $\begin{array}{c}2,33 \\
1,19-4,59\end{array}$ & $0,014^{*}$ \\
\hline Seks orogenital & $\begin{array}{c}3,07 \\
1,47-6,41\end{array}$ & $0,003^{*}$ & $\begin{array}{c}3.31 \\
1,60-6,84\end{array}$ & $0,001^{*}$ \\
\hline $\begin{array}{l}\text { Pemakaian } \\
\text { kontrasepsi } \\
\text { oral }\end{array}$ & $\begin{array}{c}1,92 \\
0,87-4,26\end{array}$ & 0,108 & & \\
\hline Log likelihood & $-101,24358$ & & $-102,55941$ & \\
\hline $\mathrm{BIC}$ & 227.98648 & & 225.51828 & \\
\hline
\end{tabular}

*signifikan (batas kemaknaan $<0,05$ )

$\mathrm{BIC}=$ Bayesian Information Criterion 
Tabel 2 pada model 1 menunjukkan bahwa variabel jumlah rokok dan melakukan seks oral memiliki hasil yang signifikan secara statistik (CI 95\% tidak melewati angka 1, p-value $\leq 0,05$ ), sedangkan pemakaian kontrasepsi oral memiliki nilai $p$ terbesar $(0,108)$ sehingga dikeluarkan pada model 2. Model 2 menunjukkan variabel jumlah rokok dan melakukan seks oral menunjukkan hasil yang signifikan secara statistik (CI 95\% tidak melewati angka 1, p-value $\leq 0,05$ ).

\section{BAHASAN}

Proporsi stres lebih besar pada kelompok kasus dibandingkan dengan kelompok kontrol. Hasil analisis bivariabel menunjukkan bahwa stres berhubungan dengan kejadian kandidiasis tetapi ketika dimasukkan dalam uji multivariabel menjadi tidak bermakna dengan. Perubahan nilai OR yang sangat berbeda dipengaruhi variabel perancu antara stres dengan kejadian KVV. Hasil ini tidak sejalan dengan penelitian lain yang menemukan bahwa terdapat hubungan antara stres dan kejadian kandidiasis $(7,8)$. Penelitian Ehrström menemukan perbedaan bermakna tingkat hormon penanda stres antara kelompok kasus dan kontrol $(p<0,02)(8)$. Hasil yang berbeda dikarenakan pengukuran stres dilakukan dengan pemeriksaan laboratorium kadar hormon stres, sedangkan pada penelitian ini menggunakan kuesioner. Penelitian lain melihat faktor psikologis meliputi kecemasan dan depresi, kepuasan hidup, harga diri, serta stres pada pasien klinik dengan hasil skor stres pada kelompok kasus lebih tinggi daripada kontrol (7). Hasil yang berbeda dengan penelitian ini dapat disebabkan perbedaan alat ukur yang digunakan pada penelitian tersebut yaitu menggunakan Perceived Stress Scale (PSS). Terdapat perbedaan populasi subjek penelitian yaitu pada pasien klinik (bukan WPS). Perbedaan hasil penelitian ini dengan penelitian sebelumnya bahwa stres sebagai faktor risiko kandidiasis masih belum konsisten, sehingga perlu dilakukan penelitian lebih lanjut mengenai hubungan antara stres dengan kejadian kandidiasis dengan desain, metode atau alat ukur stres yang berbeda yang mungkin lebih sesuai untuk WPS sebagai subjek penelitian.

Umur bukan merupakan faktor risiko kejadian kandidiasis pada WPS. Umur tidak berhubungan dengan kejadian kandidiasis. Status merokok bukan faktor risiko kejadian kandidiasis. Distribusi variabel merokok pada responden yang sehat maupun sakit tidak jauh berbeda yaitu sebagian besar merokok dibandingkan dengan yang tidak merokok. Hasil analisis bivariabel menunjukkan bahwa frekuensi merokok berhubungan dengan kandidiasis. Hasil analisis multivariabel menunjukkan bahwa frekuensi merokok >10 batang/hari berhubungan dengan kejadian kandidiasis.

Penggunaan kondom bukan faktor risiko kandidiasis. Penggunaan kondom maupun frekuensi penggunaan kondom tidak berhubungan dengan kejadian kandidiasis. Jumlah pasangan seksual $\geq 7$ orang bukan merupakan faktor risiko kejadian kandidiasis. Berdasarkan hasil univariabel diketahui bahwa distribusi jumlah pasangan seksual pada responden yang sehat tidak jauh berbeda dengan responden yang sakit yaitu jumlah pasangan seksual sebagian besar responden adalah $\geq 7$ orang. Hasil menunjukkan bahwa jumlah pasangan seksual $\geq 7$ orang tidak bermakna secara statistik dengan kejadian kandidiasis

Frekuensi hubungan seks bukan merupakan faktor risiko kejadian kandidiasis. Frekuensi hubungan seks tidak berhubungan dengan kejadian kandidiasis. Cara berhubungan seksual sebagian besar responden tidak melakukan seks secara orogenital. Melakukan seks oroggenital merupakan faktor risiko kejadian kandidiasis. Hal ini sejalan dengan penelitian Eckert et al. bahwa seks orogenital meningkatkan insiden kandidiasis (9). Frekuensi hubungan orogenital di bulan sebelum infeksi merupakan faktor risiko kandidiasis (10). Beberapa penelitian menemukan korelasi antara frekuensi seks dengan cara orogenital dan kolonisasi candida pada vagina. Hubungan seksual orogenital reseptif (laki-laki ke perempuan) secara konsisten muncul sebagai faktor risiko $(11,12)$. Hal ini menunjukkan bahwa seks orogenital meningkatkan risiko kandidiasis. Hasil penelitian ini mendukung berbagai penelitian lain yang menemukan seks orogenital sebagai faktor yang berhubungan dengan kejadian kandidiasis.

Penggunaan IUD tidak berhubungan dengan kejadian kandidiasis sehingga penggunaan IUD bukan merupakan faktor risiko, pemakaian alat kontrasepsi oral berhubungan dengan kejadian kandidiasis, namun pada uji multivariabel tidak berhubungan dengan kejadian kandidiasis, sehingga pemakaian alat kontrasepsi oral bukan merupakan faktor risiko.

Sebagian besar responden tidak menggunakan pantyliner. Meskipun ditemukan proporsi penggunaan pantyliner lebih tinggi pada responden yang mengalami kandidiasis dibandingkan dengan yang sehat, namun hasil analisis bivariabel menunjukkan bahwa perbedaan tersebut tidak bermakna secara statistik, yang artinya tidak berhubungan dengan 
kejadian kandidiasis. Hal ini menunjukkan bahwa penggunaan pantyliner bukan merupakan faktor risiko.

Vaginal douching tidak berhubungan dengan kejadian kandidiasis, sehingga vaginal douching bukan merupakan faktor risiko. Hal ini karena proporsi vaginal douching pada responden yang sehat maupun yang mengalami kandidiasis hampir sama. Obesitas tidak berhubungan dengan kejadian kandidiasis. Hasil penelitian ini menunjukkan bahwa obesitas bukan merupakan faktor risiko.

\section{SIMPULAN}

Faktor risiko kandidiasis adalah hubungan seksual dengan seks oral dan merokok $\geq 10$ batang/hari. Direkomendasikan untuk menghindari hubungan seksual dengan cara seks oral dan merokok dengan jumlah <10 batang/hari untuk menghindari risiko infeksi kandidiasis.

\section{Abstrak \\ Tujuan: Penelitian ini bertujuan untuk mengetahui hubungan antara stres psikososial dengan kejadian kandidiasis. Metode: Penelitian case control dilakukan di klinik IMS di Banyumas. Besar sampel sebanyak 164 WPS (82 kasus dan 82 kontrol). Instrumen penelitian adalah kuesioner terstruktur, kuesioner stres Social Readjustment Rating Scale (SRRS), timbangan berat badan, mikrotoise, serta peralatan laboratorium dan mikroskop. Analisis data menggunakan logistic regression. Hasil: Stres tidak berhubungan dengan kandidiasis. Faktor risiko yang berkontribusi terhadap kejadian kandidiasis pada WPS adalah melakukan hubungan seksual dengan seks oral dan merokok lebih dari 10 batang/hari. Simpulan: Faktor risiko kejadian kandidiasis adalah hubungan seksual dengan seks orogenital dan merokok $\geq 10$ batang/hari. Direkomendasikan untuk menghindari hubungan seksual dengan cara seks orogenital dan merokok dengan jumlah $<10$ batang/hari untuk menghindari risiko infeksi.}

Kata kunci: stres psikososial; kandidiasis vulvovaginal; wanita pekerja seks; case control

\section{PUSTAKA}

1. Sobel JD. Vulvovaginal candidosis. The Lancet. 2007 Jun 9;369(9577):1961-71.

2. Lanchares JL, Hernandez ML. Recurrent vaginal candidiasis changes in etiopathogenical patterns. International Journal of Gynecology \& Obstetrics. 2000 Dec 1;71(S1):29-35.

3. Reed BD, Gorenflo DW, Gillespie BW, Pierson CL, Zazove P. Sexual behaviors and other risk factors for Candida vulvovaginitis. Journal of women's health \& gender-based medicine. 2000 Jul 1;9(6):645-55.

4. Patel DA, Gillespie B, Sobel JD, Leaman D, Nyirjesy P, Weitz MV, Foxman B. Risk factors for recurrent vulvovaginal candidiasis in women receiving maintenance antifungal therapy: results of a prospective cohort study. American Journal of Obstetrics \& Gynecology. 2004 Mar 1;190(3):644-53.

5. Dobrokhotova YuE, Borovkova EI, Bondarenko KR. Candidiasis vulvovaginitis: the state of knowledge of the problem. Rossiiskii Vestnik Akushera-Ginekologa. 2017 May 1; 17 (3).

6. Holmes $\mathrm{TH}$, Rahe $\mathrm{RH}$. The social readjustment rating scale. Journal of psychosomatic research. 1967 Aug 1;11(2):213-8.

7. Sumedhi H. Korelasi antara Stresor Psikososial, Pola Perilaku Tipe A dan depresi pada Wanita Pengusaha Anggota IWAPI Cabang Yogyakarta; Penyusunan Instrumen Stresor Psikososial Modifikasi Social Readjusment Rating Scale (SRRS). 1991.

8. Irving G, Miller D, Robinson A, Reynolds S, Copas AJ. Psychological factors associated with recurrent vaginal candidiasis: a preliminary study. Sexually transmitted infections. 1998 Oct 1;74(5):334-8.

9. Ehrström S, Kornfeld D, Rylander E. Perceived stress in women with recurrent vulvovaginal candidiasis. Journal of Psychosomatic Obstetrics \& Gynecology. 2007 Jan 1;28(3):169-76.

10. Eckert L, Hawes SE, Stevens CE, Koutsky LA, Eschenbach DA, Holmes KK. Vulvovaginal candidiasis: clinical manifestations, risk factors, management algorithm. Obstetrics \& Gynecology. 1998 Nov 1;92(5):757-65.

11. Farage M, Bramante M, Otaka Y, Sobel J. Do panty liners promote vulvovaginal candidiasis or urinary tract infections?: A review of the scientific evidence. European Journal of Obstetrics and Gynecology and Reproductive Biology. 2007 May 1;132(1):8-19.

12. Bradshaw CS, Morton AN, Garland SM, Morris MB, Moss LM, Fairley CK. Higher-risk behavioral practices associated with bacterial vaginosis compared with vaginal candidiasis. Obstetrics \& Gynecology. 2005 Jul 1;106(1):105-14.

13. Spinillo A, Carratta L, Pizzoli G, Lombardi G, Cavanna C, Michelone G, Guaschino S. Recurrent vaginal candidiasis. Results of a cohort study of sexual transmission and intestinal reservoir. The Journal of reproductive medicine. 1992 Apr;37(4):343-7. 